\title{
Distribution and Seroprevalence of PPR Virus in Chad During 2004 - 2014
}

\author{
BIDJEH Kebkiba ${ }^{1, ~ *, ~ B A N-B O ~ B e b a n t o ~ A n t i p a s ~}{ }^{2}$, MAHAMAT Fayiz Abakar1, \\ ASSANDI Oussiguere ${ }^{1}$, ASSANE Kembe ${ }^{1}$, TCHARI Doungous ${ }^{1}$, KEILAR Aurelie ${ }^{1}$, \\ TAÏTOUIN Sounkreo ${ }^{3}$
}

${ }^{1}$ Department of Animal Health, Livestock Research Institute for Development, N'Djamena, Chad

${ }^{2}$ Department of Faculty of Exact and Applied Sciences, University of N'Djamena, N'Djamena, Chad

${ }^{3}$ Epidemiology Unit, Directorate of Veterinary Services, N'Djamena, Chad

\section{Email address:}

bidjehkebkiba@yahoo.fr (B. Kebkiba)

\section{To cite this article:}

BIDJEH Kebkiba, BAN-BO Bebanto Antipas, MAHAMAT Fayiz Abakar, ASSANDI Oussiguere, ASSANE Kembe, TCHARI Doungous, KEILAR Aurelie, TAÏTOUIN Sounkreo. Distribution and Seroprevalence of PPR Virus in Chad During 2004 - 2014. Animal and Veterinary Sciences. Vol. 3, No. 3, 2015, pp. 89-93. doi: 10.11648/j.avs.20150303.13

\begin{abstract}
Peste des petits ruminants (PPR) is an acute febrile viral disease of goats and sheep characterized by mucopurulent nasal and ocular discharge, erosive and necrotizing stomatitis, enteritis and pneumonia. It is widespread, virulent and devastating causing significant impacts to the economy, food security and livelihoods of poor marginalized farmers. This study focused on clinical observations of 233 suspected cases of PPR and provided detailed information on the prevalence of antibodies against the PPR virus in sera from 986 small ruminants and 31 from camels. Most of specimens for this study were obtained from the slaughterhouse in N'Djamena. Sera for the detection of antibodies against the PPR virus were not necessarily representative of the target population, even if they were from a larger number of regions. According to information provided by the epidemiological surveillance field agents, the foci of the disease were more severe in goats than in sheep and the outbreaks frequency was higher during the Cold dry season (December to June) than during the other months of the year. Analysis of 1017 sera collected in small ruminants and camels revealed that the prevalence of antibodies against the PPR virus was 34.48\%. The prevalence of antibodies against the PPR virus varied by species (goats, $15.21 \%$, sheep, $19.25 \%$ and camels, $0 \%$ ), age groups and geographic areas. The rate of infection by the PPR virus was higher in the sheep population (34. 67\%) than in goats (27.37\%). The study showed seroprevalence higher in sheep than in goats. In contrast, no serum from camels revealed positive vis-à-vis the PPR virus. Another serological survey would need to be undertaken in the population of camels in order to clarify their role in the epidemiology of PPR.
\end{abstract}

Keywords: PPR, Virus, Serum, Sheep, Goats, Camels, Chad

\section{Introduction}

Peste des petits ruminants (PPR) is a disease of small ruminants widespread [26, 27], virulent and devastating causing significant impacts to the economy, food security and livelihoods of marginal farmers in Africa and south Asia. It is an important concern for food security and poverty alleviation The disease is caused by a morbillivirus [9] closely related to rinderpest virus eradicated worldwide in 2011. PPR is considered as one of the most damaging animal diseases in Africa, the Middle East and Asia. It is also one of the priority diseases identified in the World 5-year Action Plan (2013-2017) of the FAO-OIE Global Framework for the
Progressive Control of Transboundary Animal Diseases (GF-TADs).

Formerly it was supposed to be confined in West Africa, but now rampant in Oman [27], Sudan and the United Arab Emirates [8]. The isolation of the virus in the gazelle (Gazella dorcas) poses the problem of the role of wildlife in the epidemiology of this disease [13]. It was described for the first time in 1942 by Gargadennec and Lalanne in Ivory Coast [6]. The disease is characterized by fever, the onset of clinical signs, state of exhaustion, hyperthermia, oculo-nasal discharge, oral lesions, breathing difficulty with cough, foul-smelling diarrhea, and ends in many cases by the death of the animal [28]. 
In Chad, the disease is endemic and causes significant economic losses each year related to high morbidity (90\%) and mortality $(80 \%)$ in infected goats and sheep [2,23].

This disease is particularly prevalent in areas where the conditions are ripe for hatching and remain in the animals whose maintenance is usually not satisfactory. This is the case in Chad where the disease has long time existed [22, 23].

All African countries located between the Sahara and the equator in the Atlantic Ocean to the Red Sea, are in the endemic area of PPR [20]. North Africa, excepted Egypt and Morocco, is not affected by PPR virus. It is the same for Southern Africa.

In Chad, the population of small ruminants has been no mass vaccination campaign against the disease. Yet the suspicion of the existence of the disease confirmed by serological surveys [22] and then by the isolation of the pathogen [3] requires a prophylactic action throughout the national territory. If the research has been undertaken in the meantime on small ruminants, there is no information related to the sensitivity of the Chadian camels to PPR virus. In the light of the information available in Ethiopia and Sudan, a serological survey is needed to determine the status of Chadian camels vis-à- vis the PPR virus.

Pneumonia episodes of camels found in Sudan and confirmed as PPR [17] reinforce the first viral identification work in Ethiopia where was observed an emerging disease of camels, characterized by a fever and respiratory syndrome with very high morbidity and variable mortality. The similarity of these syndromes with those of the PPR pushed research towards morbillivirus of ruminants, peste des petits ruminants and rinderpest virus [24]. This pathology of camel has since been confirmed in Sudan as the PPR [17].

This pathology similar to rinderpest clinically and antigenically $[12,18,12]$ reveals of paramount importance and growing because the economic losses associated with high morbidity (about 100\%) and mortality (about 90\%) in infected goats and sheep are considerable. The pathogen is a virus belonging to family Paramyxoviridae and the genus Morbillivirus [10]. The PPR virus was isolated for the first time in cell culture of sheep kidney by Gilbert et al. (1962) [11]. For a long time the virus was considered as a mutant of rinderpest virus adapted to small ruminants and which has lost its pathogenicity in this adaptation process for cattle. But soon after, with the development of molecular biology technologies, it has been shown that the PPR virus is a separate entity, but closely related antigenically to Rinderpest virus [7, 10].

The purpose of this work is to know the distribution of PPR in the Republic of Chad and present the seroprevalence of PPR in the areas of concentration of small ruminants in the country in order to provide basic information for launching a mass vaccination campaign against this formidable virus.

\section{Materials and Methods}

Sera were collected from sheep (548), goats (438) and camels (31). To obtain the serum, blood was collected from the jugular vein in dry tubes " venoject $\gg$ then left at room temperature for 2 hours. After the clots are detached from the tube wall and removed. After removing the clots, the contents of the tubes are transported to the laboratory in cold where the serum is obtained by centrifugation at $3000 \mathrm{rev} / \mathrm{min}$ for 15 minutes. The sera are then frozen at minus $20^{\circ} \mathrm{C}$ until further use.

This study focused on suspected cases of PPR based on clinical signs. Information on suspicions were provided by field workers involved in the of epidemiological surveillance network of animal diseases in Chad abbreviated REPIMAT [14]. The study provided also detailed information on the prevalence of antibodies directed against the PPR virus. Most clinical indications for this study were obtained from 11 regions out of 23 that account Chad (Map 1). These are the following areas: Chari-Baguirmi, Hadjer-Lamis, Mayo-Kebbi East and West, Tandjilé, Logone Oriental Mandoul, Moyen chari, Guera, Wadi-Fira and Ouaddaï. Sera were collected mainly from the slaughterhouse in N'Djamena. Analysis of sera was performed by competitive ELISA according to the protocol specified by the manufacturer. The ELISA kit used for this work is that marketed by IDvet. It was kindly provided by the International Atomic Energy Agency (IAEA).

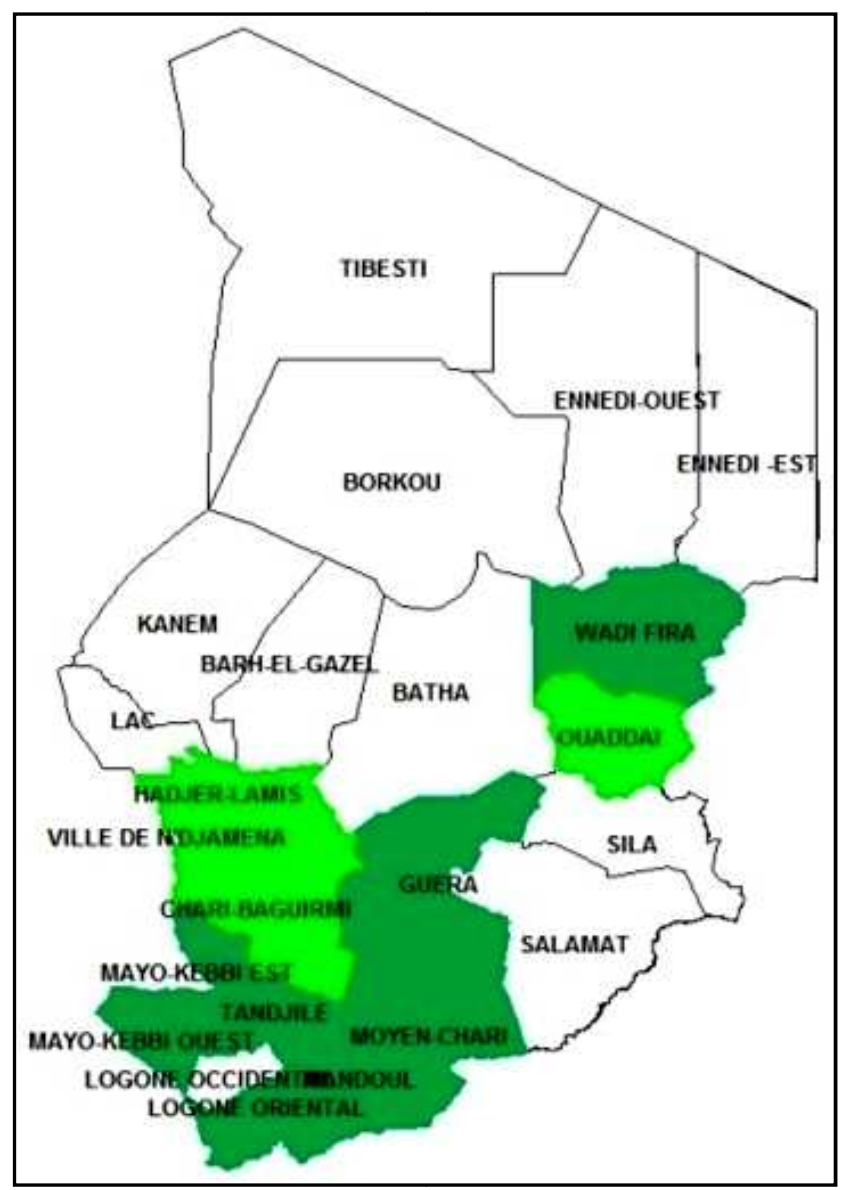

Figure 1. Administrative division of Chad: The colored areas indicate areas where there has been suspected the PPR virus.

Information relating to the PPR was collected from 2004 to 2014 in the field through epidemiological surveillance agents trained on the recognition of clinical signs of the disease. Samples taken during these suspicions were sent to the 
laboratory for diagnostic confirmation.

\section{Results}

Table 1 shows the number of suspected cases of the disease by region and year. From this table we can see that it is mostly in 2010 and 2011 when there were more suspicions of the disease. According to field workers, clinical signs are mostly seen on goats and lesser extent on sheep. These suspicions are based mainly on clinical signs of disease, but all are not confirmed by the laboratory for various reasons: Non-compliant and / or poorly preserved specimens.

Table 1. Distribution of suspected cases of PPR by year and region.

\begin{tabular}{llll}
\hline Period (years) & Number of suspicions & Localities (regions) & Laboratory confirmation \\
\hline 2004 & 27 & & $02 \mathrm{C}$ \\
2005 & 15 & Logone Oriental, Mandoul, Chari- Baguirmi, Ouaddai Tandjilé, Guera & $01 \mathrm{C}$ \\
2006 & 06 & Logone Oriental, Chari-Baguirmi, Hadjer- Lamis & NC \\
2007 & 18 & Wadi -Fira, Mandoul, Hadjer-Lamis & $01 \mathrm{C}$ \\
2008 & 14 & Mandoul, Hadjer- Lamis, Wadi- Fira & $14 \mathrm{C}$ \\
2009 & 08 & Mandoul, Hadjer-Lamis, Lac, Logone Oriental, Wadi-Fira & $03 \mathrm{C}$ \\
2010 & 66 & Moyen Chari, Mandoul, Hadjer-Lamis & $11 \mathrm{C}$ \\
2011 & 45 & Hadjer -Lamis & $02 \mathrm{C}$ \\
2012 & 28 & Ouaddaï, Chari-baguirmi, Mandoul, Logone Oriental & $01 \mathrm{C}$ \\
2013 & 03 & Moyen Chari, Tandjilé & NC \\
2014 & 03 & Hadjer - Lamis Tandjilé & $03 \mathrm{C}$ \\
Grand Total & 233 & & 38 \\
\hline
\end{tabular}

Sources : Epidemiological surveillance network of animal diseases in Chad (REPIMAT)

Legends : $\mathrm{NC}=$ no confirmed $; \mathrm{C}=$ confirmed

As it can be seen in Map 1, a total of 11 regions out of 23 $(18,18 \%)$ in the country are affected by the disease. These regions are located in the eastern, central, south and southwest of the country.

Out of 233 suspicion cases recorded from 2004 to 2014, only $38(16,30 \%)$ were confirmed by the laboratory.

In total 1017 sera with 548 from sheep, 438 from goats and 31 from camels were collected at the slaughterhouse in N'Djamena. The analysis of these sera showed a prevalence rate of $34.48 \%$ in small ruminants which $19.26 \%$ for sheep and $15.21 \%$ for goats.

Considering the number of sera collected from sheep and goats, we observe the PPR prevalence rate of $34.67 \%$ and $27.37 \%$ respectively. No camel serum was positive vis-à-vis the PPR virus.

\section{Discussion}

The data collected from the field indicate that the clinical signs are mostly seen on goats. This is explained by the fact that the goats are more sensitive to the PPR virus than sheep. These observations are similar to those described by Bidjeh et al. (1995) [3] and Lefèvre et al. (1990)[16].

According to the annual reports of the Ministry of Livestock [8], frequency of occurrence of outbreaks of PPR is often seen between December and June. These observations support those reported by Wosu et al. (1990) [29] and Ban-bo et al. (2014) [4] indicating that the incidence of PPR is higher during the cold dry season (December and January) that during the rainy season.

From 2004 to 2014, 233 suspected PPR cases have been recorded by the REPIMAT of which 38 (16, 30\%) were confirmed by the laboratory diagnosis. The small laboratory confirmation rate mentioned here would be due to non-availability of diagnostic reagents in the laboratory or inadequate or non-compliance samples collected in the field. Often the samples arrive at the laboratory in state of putrefaction, which does not allow the smooth running of the diagnosis. Hence the need to train field workers not only on the recognition of the disease, but also on how to perform the sampling, preservation and sending them to the laboratory.

This study showed a global seroprevalence of $34.48 \%$, with $34.67 \%$ for sheep, $27.37 \%$ for goats and $0 \%$ for camels. These results are different from those obtained by Lancelot [15] in sahelian zone of Chad indicating a global seroprevalence varying between 50 and $80 \%$. But it was similar to those mentioned by Chauhan et al. (2005) [5], Singh et al. (2009)[26] and Abraham et al. (2005)[1] and Shaila et al (1989) [25]. These authors noted that the prevalence of PPR virus is higher in sheep than in goats. This is due to the fact that goats are more sensitive to the virus and making a severe form of the disease die quickly before developing antibodies against the virus.

Of 31 sera collected on camels, none was positive vis-à-vis the PPR virus. This result differs from that reported by Abraham et al. (2005)[1]; Ozkul et al. (2002)[21] and Megersa et al. (2012)[19], who detected antibodies directed against the PPR virus in camels. The explanation that can be given to this result of $0 \%$ prevalence of PPR in camels is that these animals were perhaps not in contact with the virus because out of an area where the disease does has not yet appeared; it can also be due to the low number of samples collected. 


\section{Conclusion}

The information collected in the field from 2004 to 2014 showed that PPR has spread across much of territory of Chad. However, it remains endemic in central, eastern and southern part of countries.

The study showed a higher seroprevalence in sheep than in goats. By cons, no sera of camels were positive vis-à-vis the PPR virus.

Another serological survey would need to be undertaken in the population of camels in order to clarify their role in the epidemiology of PPR.

\section{Acknowledgments}

The authors would like to thank the International Atomic Energy Agency (IAEA) for graciously providing the ELISA kit that allowed the analysis of sera. They thank sincerely all the IRED technicians, who far and near, have contributed to the success of this study.

Our thanks also go to the site of the Directorate of Veterinary Services and REPIMAT agents, who kindly provided us with the information collected in the field.

We express our deep gratitude to the General Director of the Livestock Research Institute for Development (IRED).

\section{References}

[1] G. Abraham, A. Sintayehu, G. Libeau, E. Albina, F. Roger, Y. Laekemariam, D. Abaynech, K.M. Awoke, Antibody Against seroprevalence PPR virus in camels, cattle, goats and sheep in Ethiopia, Preventive veterinary medicine, 2005 (70), pp. 51-57.

[2] K. Bidjeh and M. Ouagal, Case PPR reported in several monitoring stations both in the Sahelian zone as Sudan, REPIMAT Bulletin, 1998 (7), pp.3.

[3] K.Bidjeh, P. Bornarel, M. Imadine and R. Lancelot, First isolation in Chad virus PPR. Rev. Elev. Med. Vet. Pays Trop., 1995, vol.48 (4), pp.295-300.

[4] Ban- bo Bebanto Antipas, Mian-Oudanang Koussou, Mopate Logténé Youssouf, Nakour Nargaye and Brahim Guihini. Knowledge of animal diseases and control methods at the Grand Kanem in Chad. Journal of Research in Biology, 2014, vol.4 (5), pp. 1387-1396

[5] C. Chauhan, Hemendra Singh Kher , K.R. Kaushal, Epidemiology of PPR in sheep and goats by serological, molecular and isolation methods in Gujarat, India, Advances in Animal and Veterinary Sciences, 2014, vol.2 4 (1), pp. 92-198.

[6] L. Gargadennec and A Lalanne, La peste des petits ruminants. Bull. Serv. Zoot. Epiz Afr. Occ. Fr., 1942 (5), pp.16-21.

[7] A. Diallo, T. Barrett, Mr. Barbon, Subbarao SM, W.P. Taylor, Differentiation of rinderpest and peste des petits ruminants viruses using cDNA clones Specific. ,J. vir. Methods, 1989 (23), pp. 127-136.

[8] Veterinary Services Department. Annual Report 2011, pp. 53.

[9] C.W. Furley, W.P.Taylor and T. U. Obi, An outbreak of PPR in a zoological collection. Vet. Record, 1987 (121), pp.443-447.
[10] E.P.J. Gibbs, W. P.Taylor, M.J. Lawman, J. Bryant, Classification of PPR virus as the fourth member of the genus Morbillivirus of. Intervirology ,1979 (11), pp.268-274.

[11] Y.Gilbert , J. Monnier, Adaptation of PPR virus to tissue cultures. Rev. Elev. Med. Vet. pays Tropicaux ,1962 (15), pp. 321-335.

[12] F.M. Hamdy, S.S. Breese, C.J. Deboer, Immunological relashionship between rinderpest and peste des petits ruminants viruses. Proc. 79 th Meet. US. Anim. Health Assoc., 1976, pp.168-179.

[13] F.M. Hedjer, I.T.R. Barnett and D.F. Gray, Some virus diseases of domestic animals in the Sultanate of Oman. Tropical Animal Health and Production, 1980 (12), pp.107-114.

[14] P. Hendrikx, K. Bidjeh, K. Ganda, M. Ouagal, H. Ali,M. Saboun, A. Maho, O.A. Idriss, Epidemiological surveillance network of animal diseases in Chad. Scientific and Technical Review of the OIE ,1997, pp.3-12.

[15] R. Lancelot, Enquête éco pathologique sur les maladies respiratoires des chèvres au Tchad, de la Recherche au développement. Capricorne, 1993, vol.7, pp.2-3.

[16] P.C. Lefèvre and A. Diallo. Peste des Petits Ruminants, Scientific and Technical Review of the Office International Des Epizooties, 1990, vol. 9 (4), pp.935- 950.

[17] A. I. Khalafalla, I .K. Saeed, Y. H. Ali, M.B. Abdurrahman, O. Kwiatek, G. Libeau; Z. Abbas, A.A. Obeida, A outbreak of PPR in camels in the Sudan, Acta Trop., 2010 (116), pp.161-165.

[18] P. Mornet, J. Orue, Y. G. Gilbert, Thiery, M. Sow, Peste des petits ruminants in French West Africa, its relations with rinderpest. Rev. Elev. Med. Vet. Pays Trop., 1956, (9) pp.313 342.

[19] B. Megersa and D.Biffa et al., Epidemic characterization and modeling within herd transmission dynamics of an emery Transboundary camel disease epidemic in Ethiopia, Tropical animal health and production, 2012, (44) pp. 1643-1651.

[20] F. Njeumi, Current scenario and control initiatives for PPR at global, regional and Countries levels according to the risk factor and socioeconomic impact. In: proceedings of the second regional conference on progressive control of PPR in south Asia, Khathamandu, Nepal, 19- 20 December 2013.

[21] A. Ozkul, Y. Akca, F. Alkan, T. Barrett, T. Karaoglu, S.B. Gagalp, J. Anderson, K. Yesilbag, C. Cokcaliskan, A. Gencay, Prevalence, distribution and host range of PPR virus, Turkey. Emerg. Infect. Dis., 2002(8), pp.708-712.

[22] A. Provost and Joubert, Peste des petits ruminants. Annual report laboratory Farcha, 1973, pp.106- 108.

[23] Y. Maurice, A. Provost and Y. C. Bourdin, PPR does exist in Central Africa? In proceedings 40th General Conference of the Committee of the OIE report, 1972, (202), pp.9.

[24] F. Roger, A. Diallo, L. Yiggezu, M. C. Hurrard, G. Libeau, G. Y Mebratu and B. Faye, Investigation of a new pathological conditions of camels in Ethiopia, Camel J. Pract. Res., 2000 (2), pp.163-166.

[25] M.S. Shaila, V. Purushothaman et al., PPR of sheep in India. Veterinary Record, 1989 (125) pp.602. 
[26] R.K .Singh, V. Balamurugan et al., Possible control of PPR in India, Technical aspects, Vet Ital., 2009(45), pp. 449-462.

[27] W.P. Taylor, The distribution and Epidemiology of PPR: In Proceeding of 4 th International Conference of Institutions for Tropical Veterinary Medicine, Orlando Florida May 9-13, 1983.
[28] P. Wohlsein and J. Saliki, Rinderpest and peste des petits ruminants virus: Plague of wide and small ruminants : Biology of animal infections, Academic Press: London, UK, 2006, pp.69-85.

[29] L.O. Wosu, I. Okiri and P. A. Enwezor, Optimal time for vaccination Against PPR in goats in the humid tropical region in southern Nigeria: In proceedings of the first biennial conference of the African small ruminant research network. AICC, Arusha, Tanzania, 1990. 